\title{
Rural Electrification with Hybrid Power System
}

\author{
Gaurav Kumar jaiswal ${ }^{1}$, Prashant Singh Rajpoot ${ }^{2}$, \\ Sharad Chandra Rajpoot ${ }^{3}$, Mamta singh ${ }^{4}$ \\ ${ }^{1}$ Asst. Prof., Electrical Engineering Department, Lakhmi Chand Engineering College, Bilaspur, Chhattisgarh, India, \\ ${ }^{2}$ Asst. Prof., Electrical Engineering Department, Lakhmi Chand Engineering College, Bilaspur, Chhattisgarh, India, \\ ${ }^{3}$ M.tech ., Electrical \& electronics Engineering Department, Dr. C.V.R.U.kota, Bilaspur, Chhattisgarh, India, \\ ${ }^{4}$ Asst. Prof., Electrical Engineering Department, Lakhmi Chand Engineering College, Bilaspur, Chhattisgarh, India,
}

\begin{abstract}
In the recent time Chhattisgarh establish new power hub in India but Chhattisgarh rural area does not have any electricity. With the simple and cheap arrangement we can provide electricity in rural area. Lots of village is not connected with power grid. We can generate electricity by use of biogas, solar, wind etc. By the use of these, there are negligible chances of pollution. With the help of photovoltaic cell and wind energy, we can produce electricity in the hilly areas and field areas. Government also promoted non conventional energy sources and provide lots of concession in the equipment of solar energy and wind energy power station. This paper presents an analysis of power supply using Solar and Wind hybrid energy in south areas of Chhattisgarh. This area includes parts of Dantewada, Jagadalpur, Bastar, and Kondagao. There are some Hilly tribal belts in south Chhattisgarh where the density of population is less than 100 persons per Sq. kilometre. Geographically this is hilly area where people live in scattered huts in mountain area where it is very costly to supply electricity to each and every hut. To enlighten these huts in dark nights and to provide them electricity for household use in each and every session is the target. Hybrid wind-solar Energy may be a boon for this areas. All the related data and graph s includes in this paper, establishment of hybrid renewable power system. The other non conventional method of method of power generation may be such as solar cells, fuel cells, thermo electric generation, thermionic convertor, wind power generation, solar power generation tidal power generation. There is also need to improve the utilization generating equipment take corrective measures to improve reliability of the electric power system and take care environmental aspects of energy generation.
\end{abstract}

Keywords: Rural Electrification ${ }^{1}$, Hybrid power system ${ }^{2}$, Photovoltaic ${ }^{3}$.

\section{Introduction}

More than $70 \%$ of total population people live in rural areas without access to grid-connected power. Many villages remain to be non electrical connected area, because it is difficult to supply electricity due to inherent problems of location and economy .Remote area village Besoli Tahasil Bastar district Bastar Chhattisgarh where found to be un electrified this paper shows the probability of enlightenment of this area by the hybrid system and HOMER software[1]. The costs to install and service the distribution lines are considerably high for rural hilly areas. Also there will be a substantial increase in transmission line losses due to high voltage [2]. In most of the remote and non-electrical connected sites, extension of utility grid lines experiences high capital speculation, high lead time, low load factor, reduced voltage regulation and frequent power supply interruptions. Hence, a convenient, economic and reliable power supply is an essential factor in the development of any rural area $[3,4]$. Thus, to overcome all the disadvantages possessed by the conventional method of electricity generation and transmission distributed energy generation is being preferred and promoted. There are several ways by which electricity can be generated locally using renewable sources such as solar, wind, etc. At present, standalone solar photovoltaic and wind systems have been promoted around the globe on a comparatively larger scale. These self-regulating systems cannot provide continuous source of energy, as they are irregular. Therefore, suitable energy storage systems will be required for these systems in order to satisfy the power demands. Usually storage system is pricey and the size has to be reduced to a minimum possible for the renewable energy system to be cost effective. The cost effective solution would be hybrid power systems which can reduce energy storage requirements. For villages, where we can get of the abundant source of sun rays and wind blow, we can use a hybrid performance employing solar and wind energy.

\section{Necessity Of Hybrid System}

Hybrid system is considered as one of the most efficient means to access electricity from locally available renewable energy resources where the access to national grid is quite impossible and also not economic. People of several places are out of reach of electricity also because of its geographical landscape and conditions where providing electricity from a centralized power plant through some sorts of transmission lines is not probable. The people reside in such kind of place can be highly benefitted by the means of hybrid system. Also seasonal and non-linear variation of renewable resources [5]. For uninterruptable power supply we have 
used a $2 \mathrm{~kW}$ diesel generator. Only for this ensure a balance and stable power output it needs to be integrated with a diesel generator. Here in our study we have developed a hybrid system for this area which consist all the load demands using Solar PV, Wind turbine and a Diesel Generator.

\section{Component Of The Proposed Hybrid System}

Considering our project site we have designed our hybrid system with power source of biogas plant, Solar power plant and Diesel power plant, Solar power plant, Thermal power plant, Geothermal plant in the south area Chhattisgarh the most abundant green energy source here when necessary wind speed for power generation will only be available for $8-9$ months. So a Thermal \& Hydro power plant is taken for stable supply of power. Hence the mechanism of our systems is:
A. WIND POWER PLANT.(WPP)
B. SOLAR POWER PLANT(SPP)
C. DISEL POWER PLANT(DPP)
D. HYDRO POWER PLANT(HPP)
E. THERMAL POWER PLANT(TPP)
F. GEOTHERMAL POWER PLANT(GPP)

\section{A. Wind power plant :}

Winds are essentially caused by solar heating of the atmosphere. Before the development of electrical power on large scale, wind power has serve Chhattisgarh the source of power earlier days called as wind mills. Wind power has been used for pump water and grind wheat and corn. A local wind mill generator may be offer a cheaper alternative in case of long transmission line are required to bring power from grid to the Chhattisgarh remote area an isolated area.

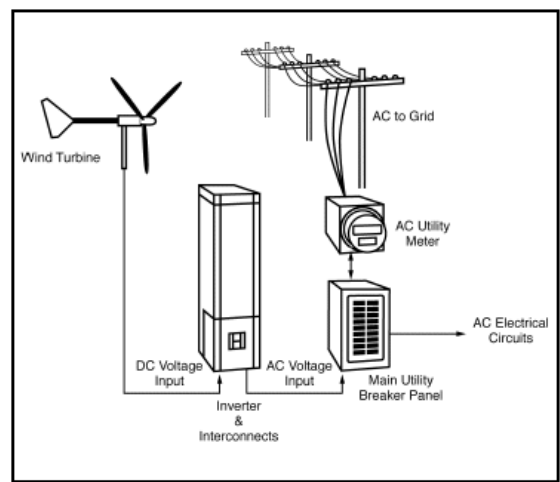

Figure: - (1) wind power generation \& supply system [4]

\section{B. Solar Power plant:-}

The solar cell or photo voltaic is converted solar energy directly to electrical energy without any intermediate thermodynamic cycle. The solar cell operate on the principal of photovoltaic effect which is a process of generating an emf as a result of absorption of ionizing radiation . the efficiency of the solar cell is low $15 \%$ but that does not matter is the solar energy free of cost. The photo voltaic effect can be observe in the nature of variety of material but the material having best performance in the sunlight are the semiconductor. The photovoltaic cell generate a voltage proportional to electromagnetic radiation intensity and are called as such because of their voltage generating capability.

Table 1:- Pv Power Plant Design Parameter [6]

\begin{tabular}{|c|c|c|c|}
\hline $\begin{array}{c}\text { System } \\
\text { capacity }\end{array}$ & $\begin{array}{c}\text { Maximum allowable } \\
\text { WH/Day }\end{array}$ & $\begin{array}{c}\text { Battery bank } \\
\text { capacity }\end{array}$ & $\begin{array}{c}\text { No of CFL of 11 } \\
\text { Watt @ 6 } \\
\text { Hr/Day }\end{array}$ \\
\hline $1 \mathrm{KW}$ & $3000 \mathrm{WHr}$ & $48-400 \mathrm{AH}$ & $30-35$ \\
\hline $2 \mathrm{KW}$ & $6000 \mathrm{WHr}$ & $48-600 \mathrm{AH}$ & $70-75$ \\
\hline $3 \mathrm{KW}$ & $9000 \mathrm{WHr}$ & $48-900 \mathrm{AH}$ & $90-100$ \\
\hline $4 \mathrm{KW}$ & $12000 \mathrm{WHr}$ & $96-600 \mathrm{AH}$ & $140-150$ \\
\hline $5 \mathrm{KW}$ & $15000 \mathrm{WHr}$ & $96-800 \mathrm{AH}$ & $180-200$ \\
\hline $6 \mathrm{KW}$ & $18000 \mathrm{WHr}$ & $96-1000 \mathrm{AH}$ & $240-250$ \\
\hline
\end{tabular}




\section{Diesel Power plant}

A diesel generator is the combination of a diesel engine with an electric generator (often an alternator) to generate electrical energy. This is a specific case of generator. Diesel generating sets are used in places without connection to the power grid, as emergency power-supply if the grid fails, as well as for more complex applications such as peak-lopping, grid support and export to the power grid. Sizing of diesel generators is critical to avoid low-load or a shortage of power and is complicated by modern electronics, specifically nonlinear loads.

\section{Hydro power plant}

The HPP power obtaining from the energy of falling water where as hydroelectric power plant is power plant utilizing the potential energy of water at high level of the generation of electrical energy the HPP water head is created by the constructing a dam across a river lake. The pressure head of the water or the kinetic energy of the water is utilize to drive the water turbine connected to the alternator and therefore generation of electrical power

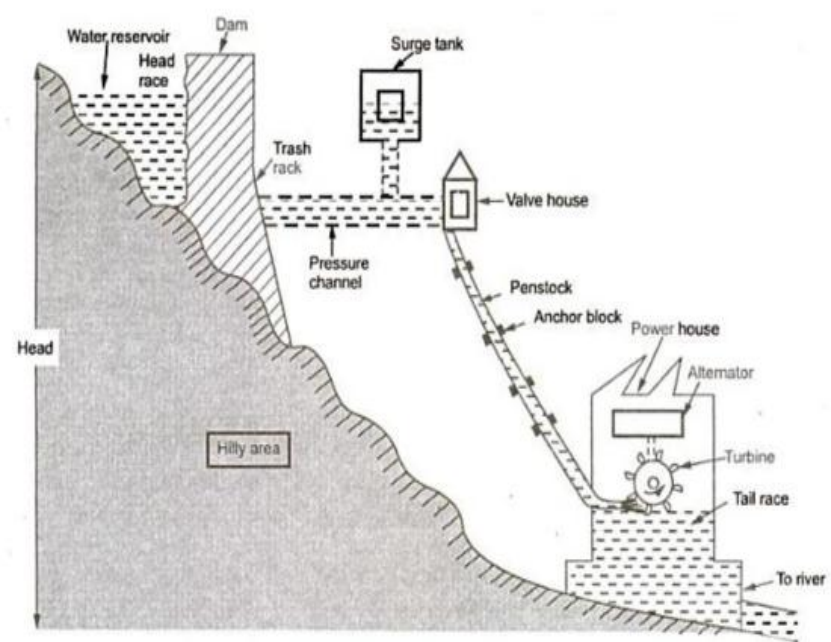

\section{E. Thermal power plant}

Figure: - (2) Hydro power generation [8]

TPP heat of combustion of fuel (coal, oil) gas it utilized by the boiler to increase steam at high pressure and temperature. The steam turbine use in the steam power plant not only acts as prime mover but also drive for auxiliary equipment such as pump, stokers fans etc. TPP may be installed to generate electrical generation of industrial purpose, agricultural. Domestic, etc.

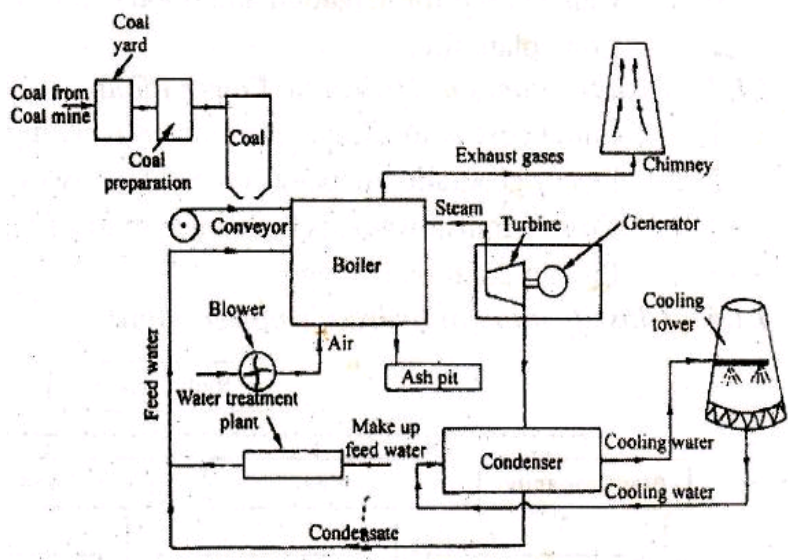

Figure: - (3) Thermal power plant generation [7]

\section{Proposed System}

Size optimization of hybrid system is done by optimization model for electric renewable software (HOMER). The proposed system contains solar power, wind power with diesel generator with battery storage system for storage of excess generated electricity $[7,8]$. Converter system connected between AC and DC link. 
The wind turbine is the major supplier of energy to this system and the variation of wind power with time, simultaneously with the domestic demand, are the only outside variables influence the system. The PV systems with battery banks share some of the loads. The diesel generators and battery banks are used as a back-up electricity source. The HOMER software determines optimal cost and sensitivity analysis of the proposed system. Firstly we describe a model configuration of the hybrid energy system that consists of Photovoltaic module system, wind turbine System, Diesel generator system and the battery storage system as our shown in fig.1

Here, by the HOMER software the simulated peak demand of primary load is $6.2 \mathrm{~kW}$ and total energy consumption is $31 \mathrm{kWh} /$ day where calculated peak demand is $6 \mathrm{~kW}$ and total energy consumption is $37.1 \mathrm{kWh} /$ day [7, 8]. Simulated result is low from the calculated result as we given balanced input load to the HOMER software of different hours of a day. The hybrid system consists of three individual generating units where the output from Wind turbine and Diesel Generator units are alternating in nature hence they are tied to AC bus-bar. Solar PV is tied to DC bus-bar because the output from solar panel is DC.

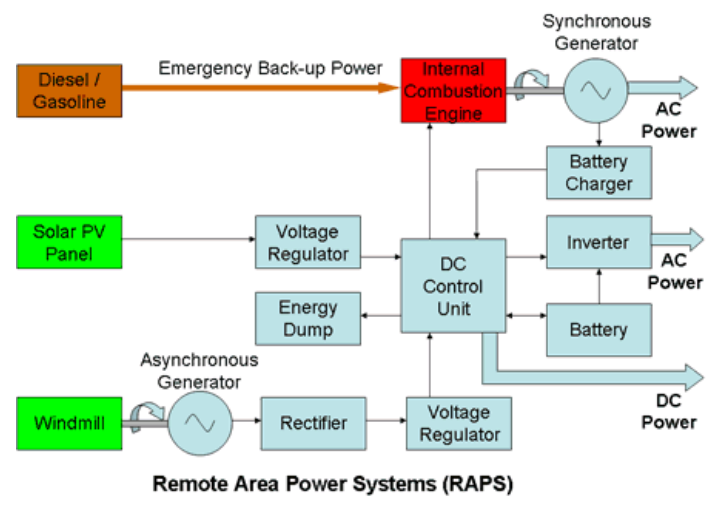

Figure (4) Hybrid power system[6]

The battery is also tied to DC bus-bar so that it can store the power delivered by solar panel when there is excess solar radiation during peak sun hours and deliver the required amount of power when the solar panel is not in operation that is during period of night, cloudy and rainy days etc. The converter is tied between AC and DC bus-bar. Converter converts the DC outputs of the PV system and battery into AC. The loads are measured to be AC loads.

\section{Electrical Results Of The Hybrid System}

The production of electricity by creature scheme in hybrid system is given below in Table2.

Table II Production KWhr/yr

\begin{tabular}{|c|c|}
\hline Production & MWhr/yr \\
\hline Thermal Power Plant & 4418 \\
\hline Hydro Power plant & 140 \\
\hline PV array & 4 \\
\hline Wind & 2 \\
\hline Other & 6 \\
\hline Total & 4570 \\
\hline
\end{tabular}

It is seen from above Table that PV array accounts for total of $79 \%$ of hybrid system production whereas Diesel Generator accounts for only 10\% and Wind turbine accounts for $11 \%$ of total electrical energy produced by the hybrid system. Since the electricity produced by Solar PV scheme is more than any other scheme participating in the hybrid system thus is considered as the base load of the hybrid system.

\section{Conclusion}

Under current acute power shortage scenario with increasing cost of natural gas, coal and turbine fuel and due to their impact on environment, there is a very urgent and great need of finding alternate source of energy to generate electricity. There are several ways by which electricity can be generated using renewable sources such as solar, wind, biogas, etc. Individual generation of solar and wind energy is costlier. Solar and wind energy integrated technologies have great potential to profit our nation. They can diversify our energy supply, decrease our dependence on imported fuels, get better the quality of the air we take breaths, offset 
greenhouse gas emissions, and stimulate our wealth by creating jobs in the manufacturing and installation of solar and wind energy systems. By using solar and wind integrated system we can electrify remote area also it is applicable for metro cities in future to avoid unwanted load shedding.

\section{Reference}

[1]. S.Rao, "Testing Commissioning Operation and Maintenance of Electrical Of Equipment”, Khanna Publishers pp 82-92

[2]. National Certification Examination for Energy Managers and Energy Auditors, "Energy Performance Assessment for Equipment and Utility Systems", Bureau of Energy Efficiency (A Statutory Body under Ministry of Power, Government of India), Book-4, pp. $158-160$.

[3]. H.M.Robert and J.H. Collins, "Handbook of Energy Conservation", CBS Publishers \& Distributors, Vol. No.-I, 2007, pp.122-138.

[4]. M. Muralikrishna and V. Lakshminarayana, "Hybrid (solar and wind) Energy System for Rural Electrification", ARPN. Journal of Engineering and Applied Sciences, Vol. 3, No. 5, October 2008 pp. 50-57.

[5]. Alliance for Rural Electrification, "Hybrid power systems based on renewable Energies; suitable and cost competitive solution for rural Electrification"

[6]. M.A. Elhadidy and S.M. Shaahid, "Parametric study of hybrid (wind + solar + diesel) power generating Systems", Journal of Renewable Energy, Vol. 21, pp. 129-139

[7]. R.Ramkumar: "Renewable Energy Resources and Developing Countries", IEEE transactions on power Apparatus and systems, Vol. PAS-102, No. 2, Feb.-1983, pp 502-510.

[8]. HOMER V2.68 beta, National Renewable Energy Laboratory (NREL), 617 Cole Boulevard,(online) Available: http://www.nrel.gov/homer. 